International Journal of Design and Manufacturing

Technology (IJDMT),

ISSN 0976 - 6995(Print), ISSN 0976 - 7002(Online)

Volume 2, Issue 1, January-December (2011), pp. 34-46

(C) IAEME, http://www.iaeme.com/ijdmt.html

\title{
OPTIMIZATION OF THE FACILITIES UTILIZATION AND IMPROVEMENT IN CERTAIN PARAMETERS OF MANUFACTURING SYSTEM USING SIMULATION
}

\author{
M.S.Kirkire ${ }^{1 *}$, G.J.Abhyankar², M.A.Palsodkar ${ }^{3}$ \\ ${ }^{1,2}$ Finolex Academy of management and Technology, \\ Ratnagiri, Maharashtra, India. \\ ${ }^{3}$ K.J.Somaiya college of Engineering, \\ Vidyavihar, Mumbai, Maharashtra, India. \\ (*Corresponding Author E-mail: milind.kirkire@ rediffmail.com)
}

\begin{abstract}
Proper utilization of manufacturing resources is of crucial importance to any manufacturing industry in today's global arena of competition. Simulation is extremely valuable tool for analyzing complex manufacturing systems. This paper presents a simulation study carried out at a flywheel manufacturing industry. This manufacturing industry required analysis of its manufacturing process in an attempt to increase its throughput and overall productivity.

The main objective of this work was to simulate the existing flywheel manufacturing system and to find whether the current layout gives maximum throughput if not to find out the maximum throughput of the facility and to find the current bottlenecks to the throughput.

The work provides information about performance of manufacturing system after optimization of certain parameters.

A simulation model of existing flywheel manufacturing system was developed using manufacturing simulation tool. The simulation output helped to answer above mentioned questions. A set of feasible modifications to the existing manufacturing process was prepared. These modifications were included in the simulation model and output of the modified model was analyzed. The results show significant amount of improvement in the parameters like throughput and the work in process (WIP).
\end{abstract}

Keywords: simulation, manufacturing system, throughput.

\section{INTRODUCTION}

A simulation of a system is the operation of a model of the system. Generally, a model intended for a simulation study is a mathematical model developed with the help of simulation software. A model is similar to but simpler than the system it represents. One 
International Journal of Design and Manufacturing Technology (IJDMT), ISSN 0976 - 6995(Print), ISSN 0976 - 7002(Online) Volume 2, Issue 1, January-December (2011), ( ) IAEME

purpose of a model is to enable the analyst to predict the effect of changes to the system. On the one hand, a model should be a close approximation to the real system and incorporate most of its salient features.

The model can be reconfigured and experimented with; usually, this is impossible, too expensive or impractical to do in the system it represents. The operation of the model can be studied, and hence, properties concerning the behavior of the actual system or its subsystem can be inferred. In its broadest sense, simulation is a tool to evaluate the performance of a system, existing or proposed, under different configurations of interest and over long periods of real time. Simulation is used before an existing system is altered or a new system built, to reduce the chances of failure to meet specifications, to eliminate unforeseen Bottlenecks, to prevent under or over-utilization of resources, and to optimize system performance.

\section{THE SIMULATION PROCESS FOR MANUFACTURING SYSTEMS ANALYSIS}

The process of simulating manufacturing systems involves the following phases:

\section{Model Design:}

The model design phase is a very important, but often overlooked, part of Simulation process. In this phase, the project participants are identified, the project Goals clearly delineated, and the basic project plan developed.

Traditionally, simulation models of these systems have been either: 1) a discrete event simulation model that tracks lots through each factory in the supply chain by considering the queuing at various work centers; or 2) a high level continuous simulation model that does not track individual lots through the factories but simply considers the gross output of each factory.

\section{Model Development}

After the preliminary work is done and the conceptual model designed, the next phase is to develop the model. This involves choosing the modeling approach, building the model, and doing verification and validation of the model. While there typically is not a lot of efficiency to be gained in choosing the modeling approach, the choice of approach can make a large difference in the subsequent model building and model execution times.

Most conventional simulation software packages used for modeling manufacturing systems take a "job-driven" worldview (also called a process interaction worldview). In this approach, manufacturing jobs are the active system entities while system resources such as machines are passive. The simulation model is created by describing how jobs move through their processing steps seizing available resources whenever they are needed. A separate record for every job in the system is created and maintained for tracking wafers or lots through the factory.

An alternative simulation methodology focuses on resource cycles. In a "resource- driven" simulation, individual jobs are passive and are "moved" or "processed" by active 
International Journal of Design and Manufacturing Technology (IJDMT), ISSN 0976 - 6995(Print), ISSN

0976 - 7002(Online) Volume 2, Issue 1, January-December (2011), ( ) IAEME

system resources such as machines and operators. Rather than maintaining a record of every job in the system, only integer counts of the numbers of jobs of particular types at different steps are necessary. The state of the system is described by the status of resources and these job counts and the execution speed and memory footprint does not change significantly as the system becomes more congested.

\section{Model Deployment}

In the model deployment phase, the main area for efficiency improvement is in executing the model. While simulations of some manufacturing systems may not take much time to run, models of complex manufacturing systems may take several hours for a single replication, particularly when details of automated material handling systems (AMHS) are included. In the available literature, it is clearly indicated that the average time for a 160 day simulation run of an IBM wafer fabrication facility with AMHS is approximately 24 hours, but that removing the AMHS system may reduce this to 3-4 hours. Mercier et al. Report that a single replication of their wafer fabrication model takes 1-2 hours of CPU time.

\section{DEVELOPMENT OF MODEL OF EXISTING MANUFACTURING SYSTEM AND ITS ANALYSIS}

An important step before building the simulation model is to structure it. This will identify the most difficult areas for the model building and highlight any additional data requirements that might have been overlooked till this stage, such as a transfer time for parts between processes. This plan typically takes the form of a sketch of the facility to be modeled. The plan should identify which element (or collection of elements) is to be used to model each real-life process. It may also contain information regarding the input and output rules to be used on key elements and a summary of the actions language that needs to be included in the elements to give the necessary degree of logical control. We may also incorporate other items (such as the cycle times of machines and the capacities of buffers) into the plan.

It is recommended to build the model incrementally and to test each stage thoroughly before building the next stage. If we do this, it is easier to find possible constraints for a model otherwise one will have to keep on searching for the constraints separately throughout the entire model.

Proper care was taken to avoid the temptation to experiment with the model before it was completed. It is better to have a complete, well-tested, model to act as a benchmark against which experimental results can be compared.

The main steps in building a model are creating elements (defining, displaying and detailing them), then linking them together with rules. We can also build more complex logic into our model by using actions such labor movement. The layout of the existing system was as shown in figure 1 . 
International Journal of Design and Manufacturing Technology (IJDMT), ISSN 0976 - 6995(Print), ISSN 0976 - 7002(Online) Volume 2, Issue 1, January-December (2011), ( ) IAEME

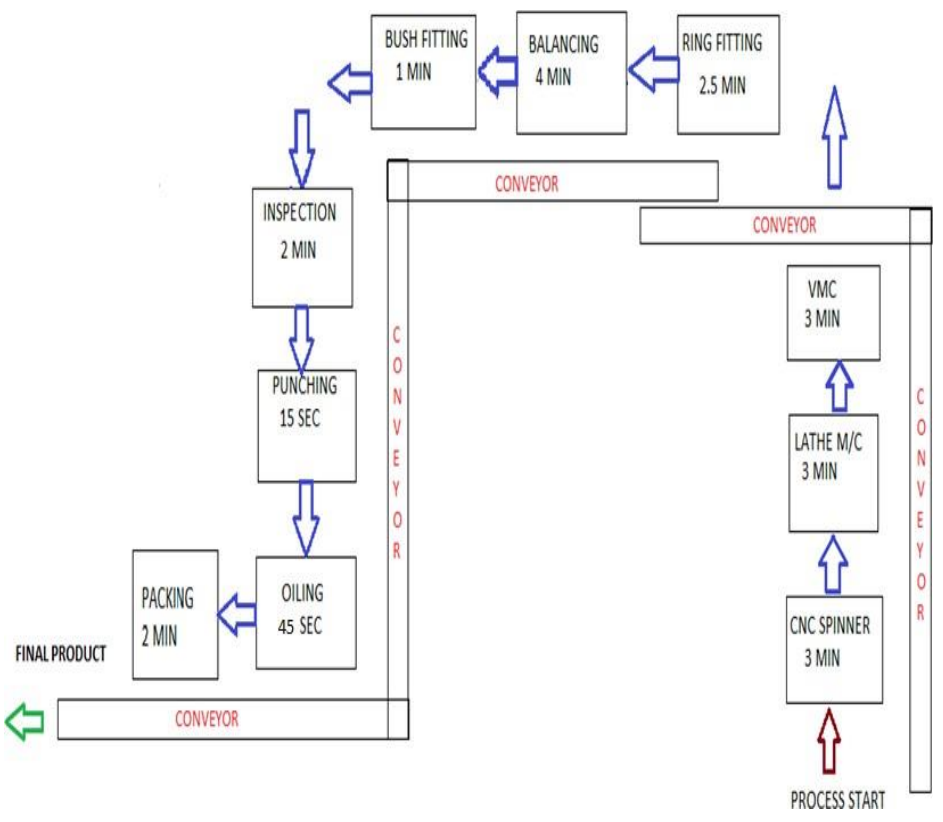

Figure 1 Process Layout of Existing Manufacturing System

The detailed data collection and time study was carried out and the entire model was built $\&$ run which resulted into the following parametric outputs.

\begin{tabular}{|l|l|l|l|l|l|}
\hline Name & $\%$ Idle & $\%$ Busy & \% blocked & $\%$ Setup & $\begin{array}{l}\text { No. Of } \\
\text { Operations }\end{array}$ \\
\hline CNC spiner & 0 & 86.73 & 10.43 & 2.84 & 9006 \\
\hline VMC & 32.01 & 65.2 & 0 & 2.79 & 4001 \\
\hline Lathe machine 01 & 0.01 & 94.88 & 0 & 5.11 & 8005 \\
\hline Ring fitting machine & 82.97 & 16.23 & 0 & 0.8 & 199 \\
\hline Bush fitting machine & 76.41 & 23.59 & 0 & 0 & 7960 \\
\hline Balancing machine & 28.65 & 70.76 & 0 & 0.5 & 7960 \\
\hline Inspection machine & 92.92 & 7.08 & 0 & 0 & 398 \\
\hline Oiling machine & 46.16 & 23.56 & 29.7 & 0.58 & 3975 \\
\hline Packing machine & 46.75 & 47.11 & 1.46 & 4.68 & 7949 \\
\hline
\end{tabular}

Table 1 Machine Performance of Existing system. 
International Journal of Design and Manufacturing Technology (IJDMT), ISSN 0976 - 6995(Print), ISSN 0976 - 7002(Online) Volume 2, Issue 1, January-December (2011), ( ) IAEME

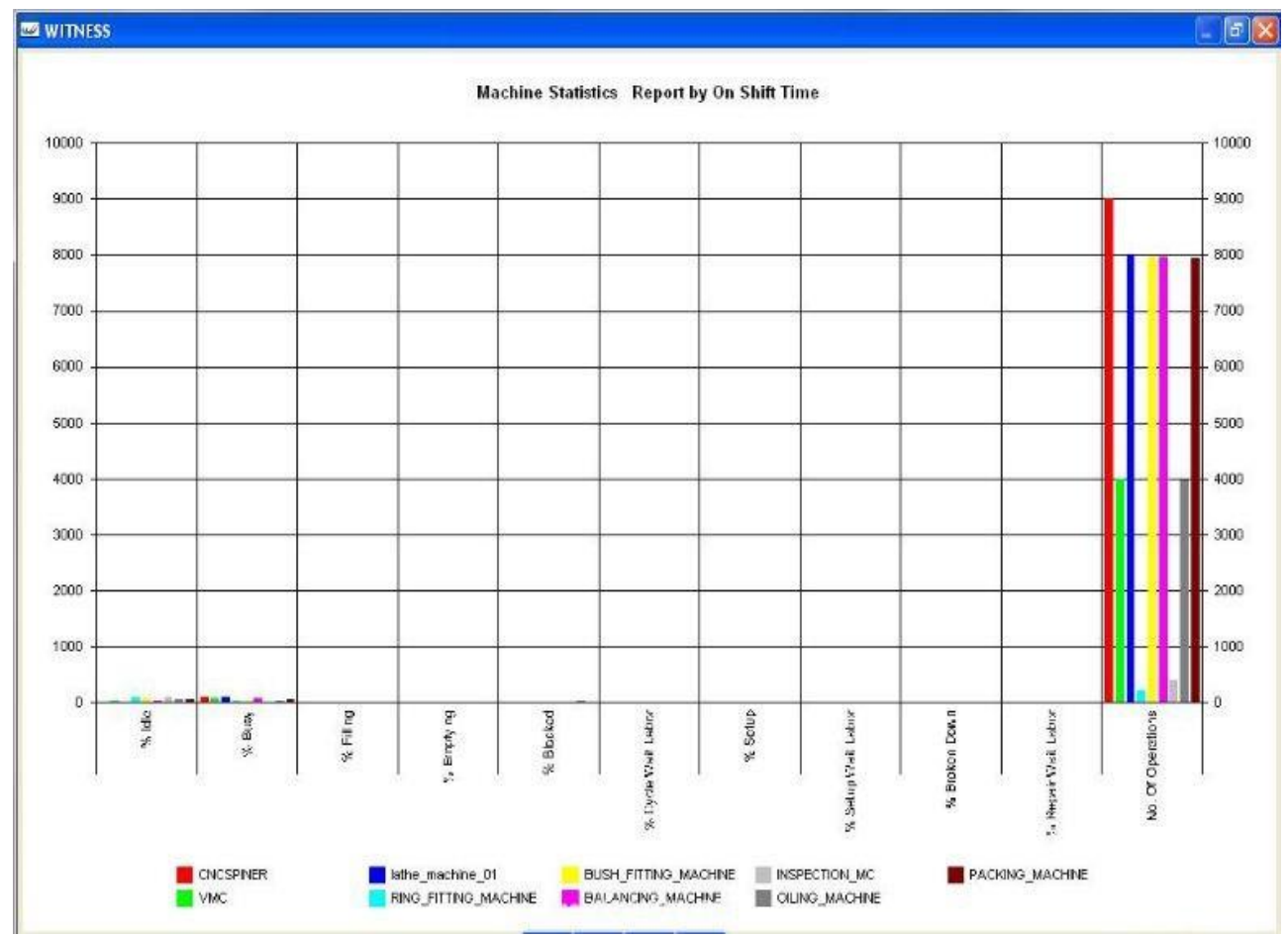

Figure 2 Machine statistics report of Existing system

3. Labor performance

\begin{tabular}{|l|l|l|l|l|l|}
\hline Name & $\%$ Busy & $\%$ Idle & $\begin{array}{l}\text { No. Of Jobs } \\
\text { Started }\end{array}$ & $\begin{array}{l}\text { No. Of } \\
\text { Jobs Ended }\end{array}$ & $\begin{array}{l}\text { Avg. Job } \\
\text { Time }\end{array}$ \\
\hline Operator lathe & 94.88 & 5.12 & 8006 & 8005 & 4 \\
\hline Operator CNC1 & 70.76 & 29.24 & 7960 & 7960 & 3 \\
\hline Operator VMC & 47.11 & 52.89 & 7950 & 7949 & 2 \\
\hline Bush fitter & 23.59 & 76.41 & 7960 & 7960 & 1 \\
\hline Packing operator2 & 86.73 & 13.27 & 9007 & 9006 & 3.25 \\
\hline Balancing operator & 65.2 & 34.8 & 4002 & 4001 & 5.5 \\
\hline Heater Labor1 & 16.23 & 83.77 & 200 & 199 & 27.5 \\
\hline Heater Labor2 & 16.23 & 83.77 & 200 & 199 & 27.5 \\
\hline Inspector 1 & 7.08 & 92.92 & 398 & 398 & 6 \\
\hline Inspector 2 & 7.08 & 92.92 & 398 & 398 & 6 \\
\hline Oil operator1 & 23.56 & 76.44 & 3976 & 3975 & 2 \\
\hline Oil operator2 & 23.56 & 76.44 & 3976 & 3975 & 2 \\
\hline Packing operator1 & 47.11 & 52.89 & 7950 & 7949 & 2 \\
\hline
\end{tabular}

Table 2 Labor performance of Existing system 
International Journal of Design and Manufacturing Technology (IJDMT), ISSN 0976 - 6995(Print), ISSN 0976 - 7002(Online) Volume 2, Issue 1, January-December (2011), ( ) IAEME

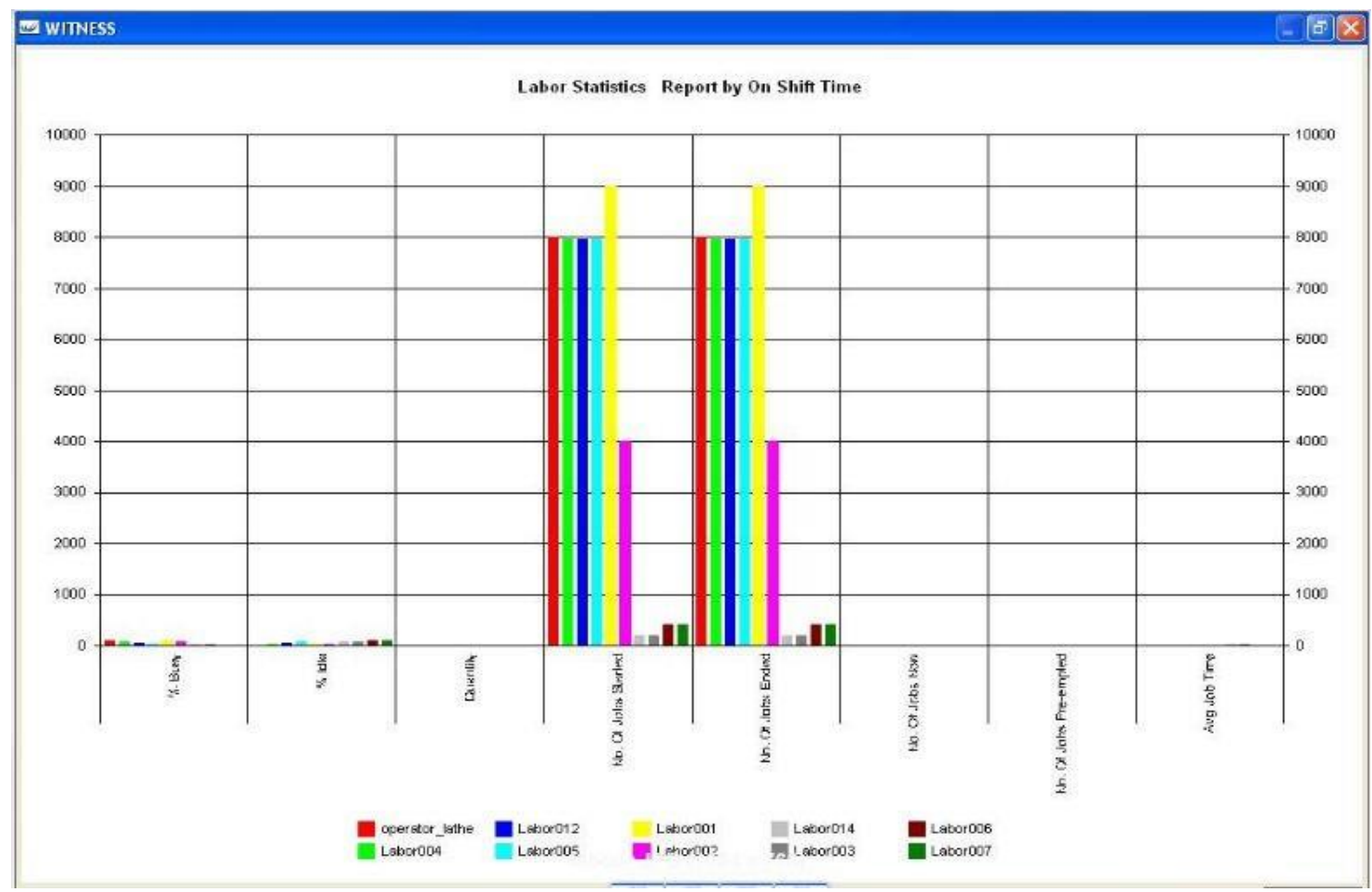

Figure 3 Labor statistics report of Existing system

3 Buffer statistics

\begin{tabular}{|l|l|l|l|l|l|}
\hline Name & $\begin{array}{l}\text { Total } \\
\text { In }\end{array}$ & Total Out & Max & $\begin{array}{l}\text { Avg. } \\
\text { Size }\end{array}$ & Avg. Time \\
\hline CNC Spiner buffer & 11007 & 9007 & 2000 & 1915.25 & 5872.59 \\
\hline Buffers002 & 8005 & 8004 & 6 & 0.39 & 1.64 \\
\hline Buffers001 & 9006 & 8006 & 1000 & 756.35 & 2834.42 \\
\hline Buffers003 & 8002 & 8000 & 28 & 0.48 & 2.01 \\
\hline Buffers007 & 7960 & 7960 & 2 & 0.02 & 0.07 \\
\hline Buffers005 & 7960 & 7960 & 56 & 14.12 & 59.88 \\
\hline Buffers006 & 7960 & 7960 & 1 & 0 & 0 \\
\hline Buffers008 & 7960 & 7952 & 136 & 7.02 & 29.75 \\
\hline Final product buffer & 17949 & 0 & 7949 & 3943.27 & 16742.41 \\
\hline
\end{tabular}

Table 3 Buffer statistics of Existing system. 
International Journal of Design and Manufacturing Technology (IJDMT), ISSN 0976 - 6995(Print), ISSN 0976 - 7002(Online) Volume 2, Issue 1, January-December (2011), ( ) IAEME

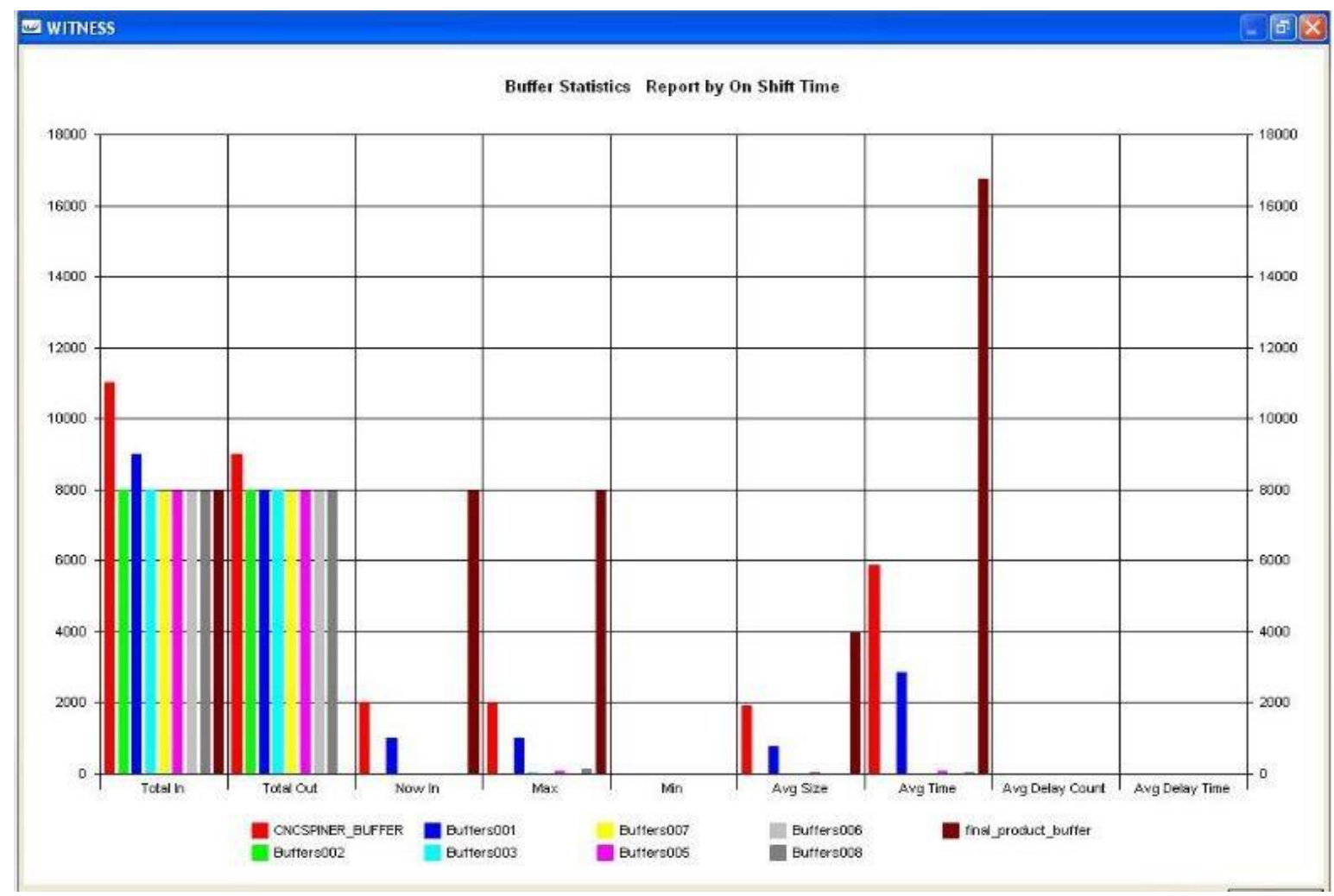

Figure 4 Buffer statistics report of Existing system.

After getting fully satisfied with the model of existing system and ensuring that the model resembles the behavior of the real-life situation, a thorough analysis was carried out, and the model was investigated for a number of what-if scenarios. The scenarios were already been defined within the original objectives of the simulation study.

\section{OPTIMIZATION OF THE PARAMETERS AND DEVELOPMENT OF THE NEW MODEL}

Successful experimentation and analysis was typically carried out using a warm-up period or starting conditions, deciding on a suitable run-length, and running the model with more than one random number streams. It led to the following alterations and results for the same.

\subsection{Statistical report for Proposed Manufacturing System:}

1. Machine performance:

\begin{tabular}{|l|l|l|l|l|l|}
\hline Name & \% Idle & $\%$ Busy & $\begin{array}{l}\% \\
\text { Blocked }\end{array}$ & $\begin{array}{l}\% \\
\text { Setup }\end{array}$ & $\begin{array}{l}\text { No. of } \\
\text { Operations }\end{array}$ \\
\hline CNC spinner & 0 & 96.84 & 0 & 3.16 & 10056 \\
\hline VMC & 14.61 & 81.89 & 0 & 3.5 & 5025 \\
\hline Lathe machine 01 & 37.24 & 59.59 & 0 & 3.17 & 5028 \\
\hline Ring fitting machine & 80.31 & 18.52 & 0 & 1.15 & 250 \\
\hline Lathe machine 02 & 37.24 & 59.59 & 0 & 3.17 & 5027 \\
\hline
\end{tabular}


International Journal of Design and Manufacturing Technology (IJDMT), ISSN 0976 - 6995(Print), ISSN 0976 - 7002(Online) Volume 2, Issue 1, January-December (2011), ( ) IAEME

\begin{tabular}{|l|l|l|l|l|l|}
\hline Bush fitting machine & 70.37 & 29.63 & 0 & 0 & 10000 \\
\hline Balancing machine & 10.34 & 88.89 & 0 & 0.65 & 10000 \\
\hline Inspection machine & 84.7 & 8.89 & 0 & 0 & 500 \\
\hline Oiling machine & 41.51 & 29.61 & 28.15 & 0.73 & 4997 \\
\hline Packing machine & 49.64 & 44.41 & 0 & 5.9 & 9992 \\
\hline
\end{tabular}

Table 4 Machine performance of proposed system

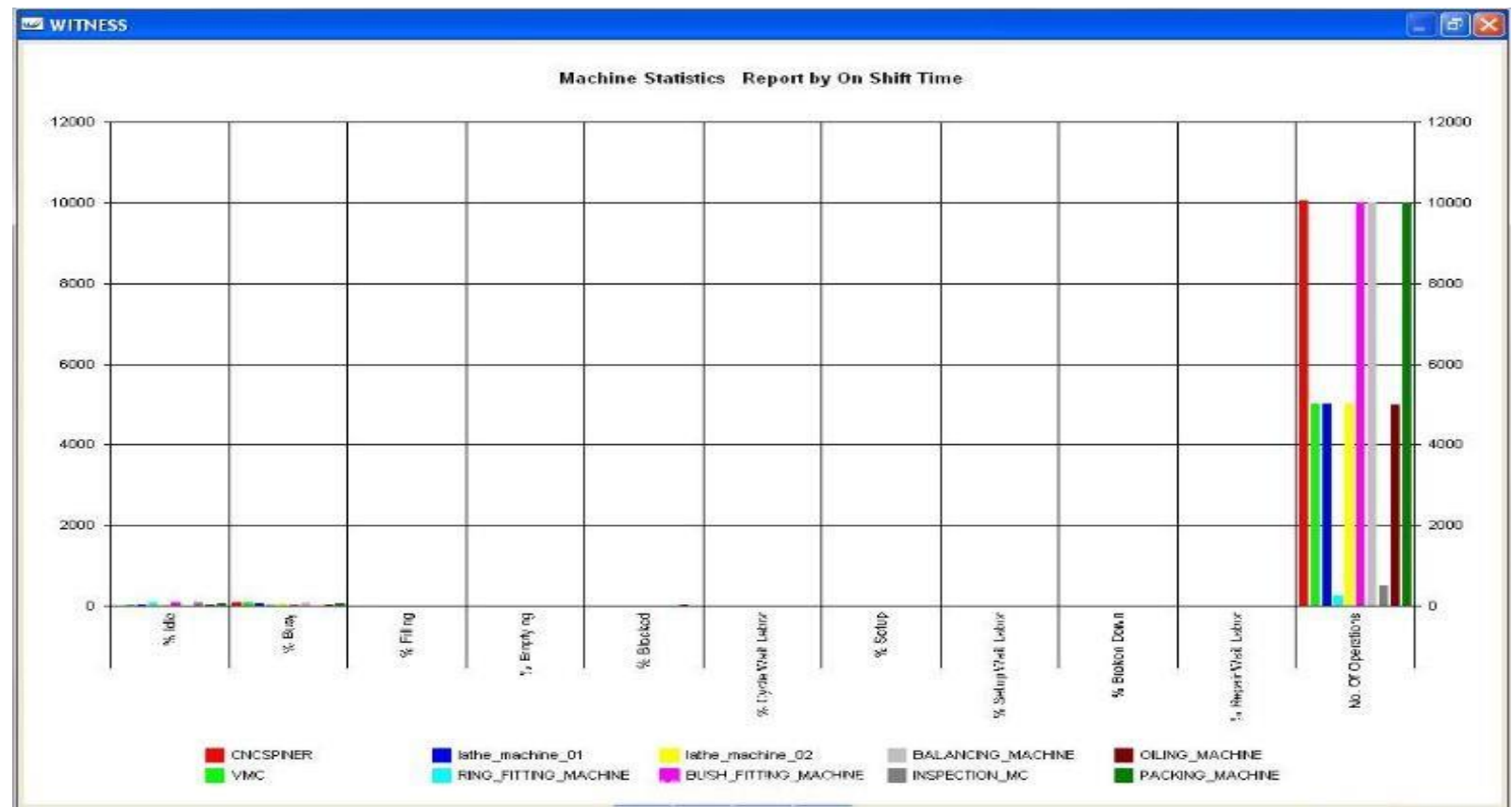

Figure 5 Machine statistics report of proposed system.

2. Labour performance

\begin{tabular}{|l|l|l|l|l|l|}
\hline Name & \% Busy & \% Idle & $\begin{array}{l}\text { No. Of } \\
\text { Jobs }\end{array}$ & $\begin{array}{l}\text { No. Of Jobs } \\
\text { Ended }\end{array}$ & $\begin{array}{l}\text { Avg. Job } \\
\text { Time }\end{array}$ \\
\hline Operator lathe1 & 59.59 & 40.41 & 5028 & 5028 & 4 \\
\hline Operator CNC1 & 88.89 & 11.11 & 10000 & 10000 & 3 \\
\hline Operator VMC & 44.41 & 55.59 & 9993 & 9992 & 1.5 \\
\hline Bush fitter & 29.63 & 70.37 & 10000 & 10000 & 1 \\
\hline Operator lathe2 & 96.84 & 3.16 & 10057 & 10056 & 3.25 \\
\hline Balanc. Operator & 81.89 & 18.11 & 5026 & 5025 & 5.5 \\
\hline Heater Labor1 & 18.52 & 81.48 & 250 & 250 & 25 \\
\hline Heater Labor2 & 18.52 & 81.48 & 250 & 250 & 25 \\
\hline Inspector 1 & 59.59 & 40.41 & 5028 & 5027 & 4 \\
\hline Inspector 2 & 8.89 & 91.11 & 500 & 500 & 6 \\
\hline Oil operator1 & 27.41 & 72.59 & 750 & 750 & 12.33 \\
\hline Oil operator2 & 53.3 & 46.7 & 10493 & 10492 & 1.71 \\
\hline Packing operator1 & 29.61 & 70.39 & 4997 & 4997 & 2 \\
\hline Packing operator2 & 29.61 & 70.39 & 4997 & 4997 & 2 \\
\hline Inspector 3 & 44.41 & 55.59 & 9993 & 9992 & 1.5 \\
\hline
\end{tabular}


International Journal of Design and Manufacturing Technology (IJDMT), ISSN 0976 - 6995(Print), ISSN 0976 - 7002(Online) Volume 2, Issue 1, January-December (2011), @ IAEME

Table 5 Labor performance of proposed system

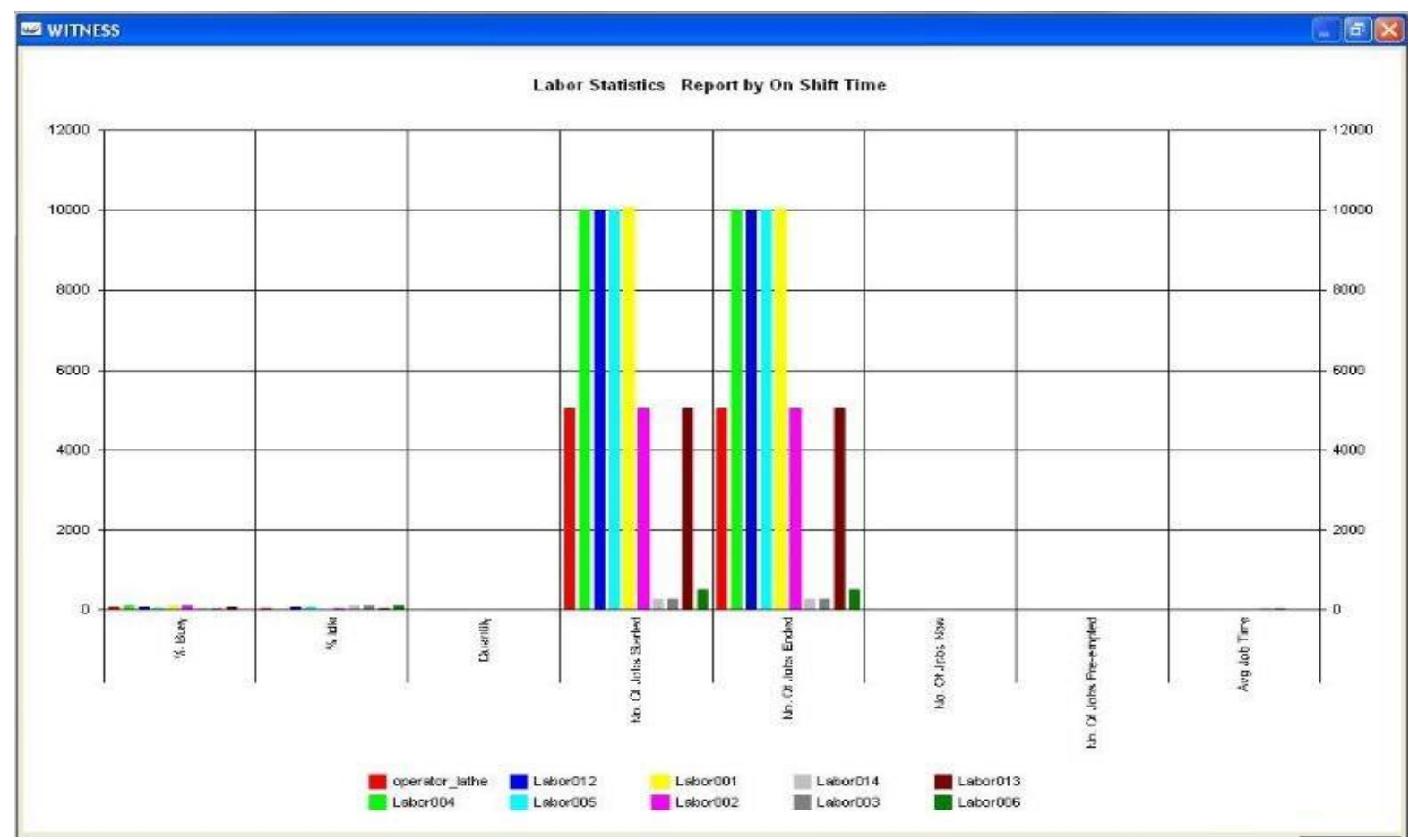

Figure 6 Labor statistics report of proposed system.

3 Buffer statistics:

\begin{tabular}{|l|l|l|l|l|l|}
\hline Name & Total In & Total Out & Max & Avg. Size & Avg. Time \\
\hline CNC spiner buffer & 12057 & 10057 & 2000 & 1915.24 & 5361.15 \\
\hline Buffers002 & 10055 & 10052 & 13 & 1.39 & 4.65 \\
\hline Buffers001 & 10056 & 10056 & 7 & 0.21 & 0.7 \\
\hline Buffers003 & 10050 & 10040 & 34 & 0.65 & 2.18 \\
\hline Buffers007 & 10000 & 10000 & 10 & 0.05 & 0.18 \\
\hline Buffers005 & 10000 & 10000 & 66 & 19.03 & 64.21 \\
\hline Buffers006 & 10000 & 10000 & 1 & 0 & 0 \\
\hline Buffers008 & 10000 & 9994 & 20 & 5.57 & 18.79 \\
\hline Final product buffer & 9992 & 0 & 9992 & 4958.63 & 16748.77 \\
\hline
\end{tabular}

Table 6 Buffer statistics of proposed system. 
International Journal of Design and Manufacturing Technology (IJDMT), ISSN 0976 - 6995(Print), ISSN 0976 - 7002(Online) Volume 2, Issue 1, January-December (2011), ( ) IAEME

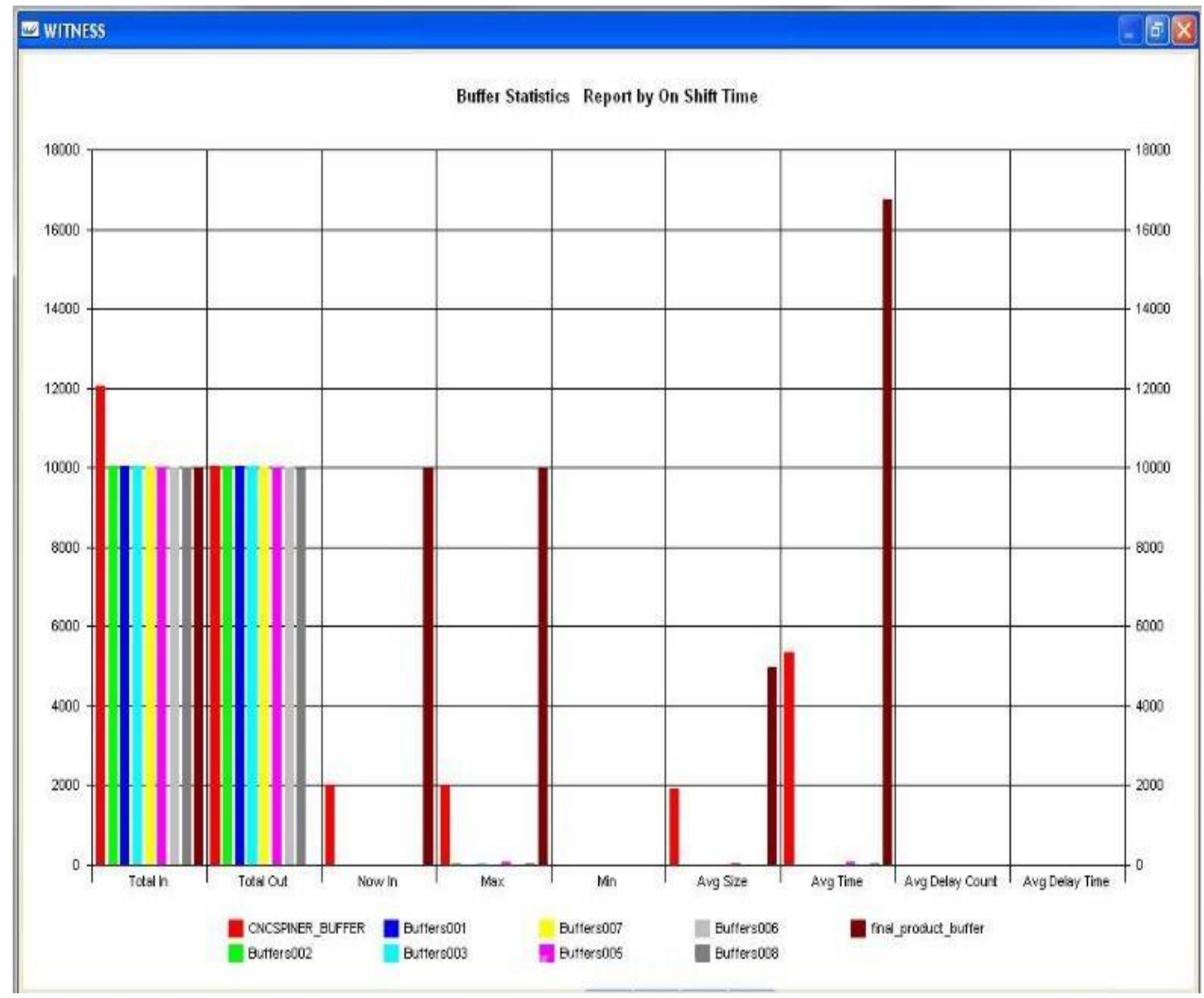

Figure 7 Buffer statistics of proposed system

\section{CONCLUSIONS}

Using the statistical data of machines of existing and proposed model, we have plotted graph, which clearly indicates that increase in machine's busy time as compared to existing model.

Considering machine busy time: 
International Journal of Design and Manufacturing Technology (IJDMT), ISSN 0976 - 6995(Print), ISSN 0976 - 7002(Online) Volume 2, Issue 1, January-December (2011), @ IAEME

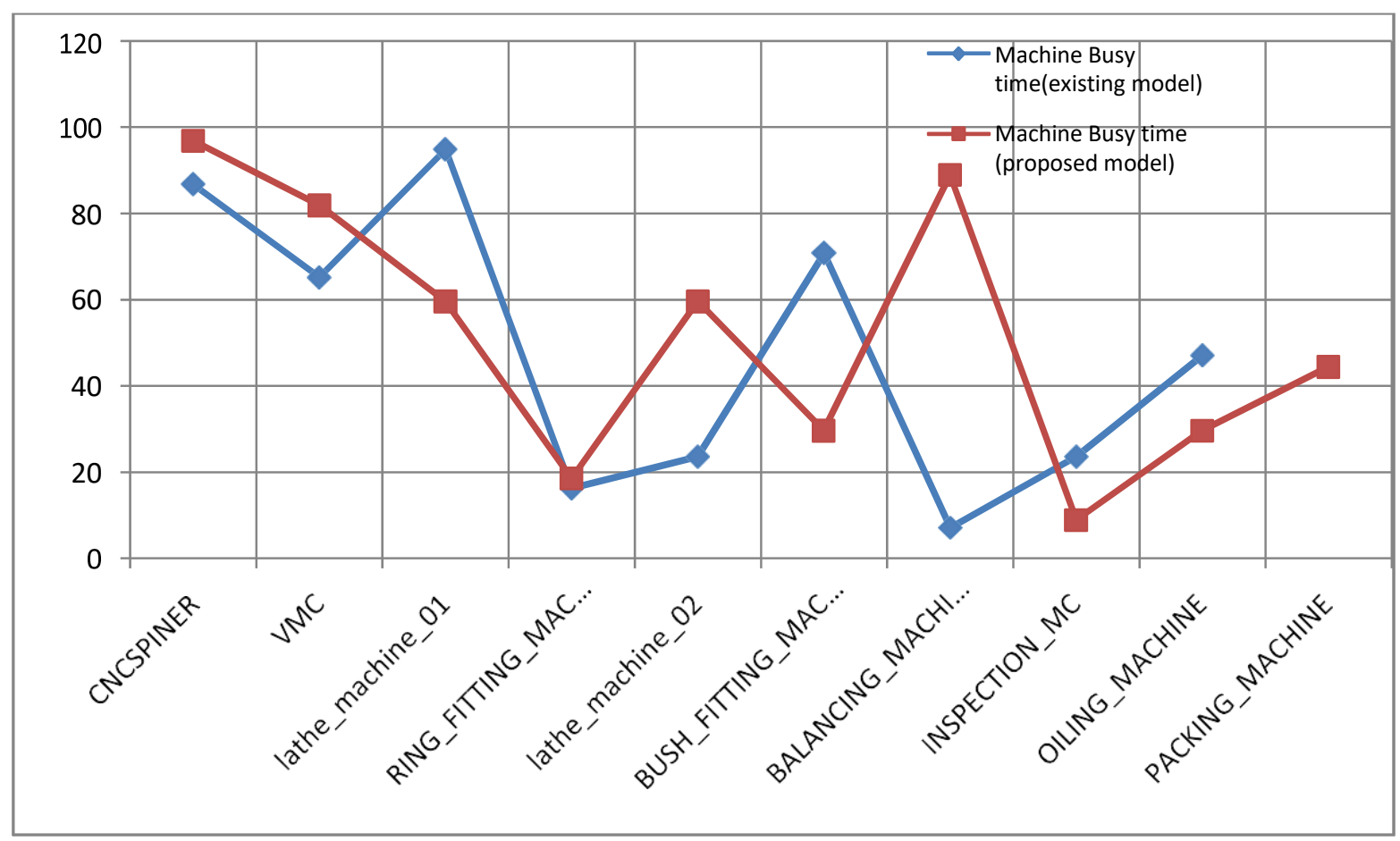

Figure 8 Comparison by machining time.

Considering labor busy time:

Using labor statistical report data, combined graph is plotted for existing and proposed model, which shows the labor performance in both models. 
International Journal of Design and Manufacturing Technology (IJDMT), ISSN 0976 - 6995(Print), ISSN 0976 - 7002(Online) Volume 2, Issue 1, January-December (2011), ( I IAEME

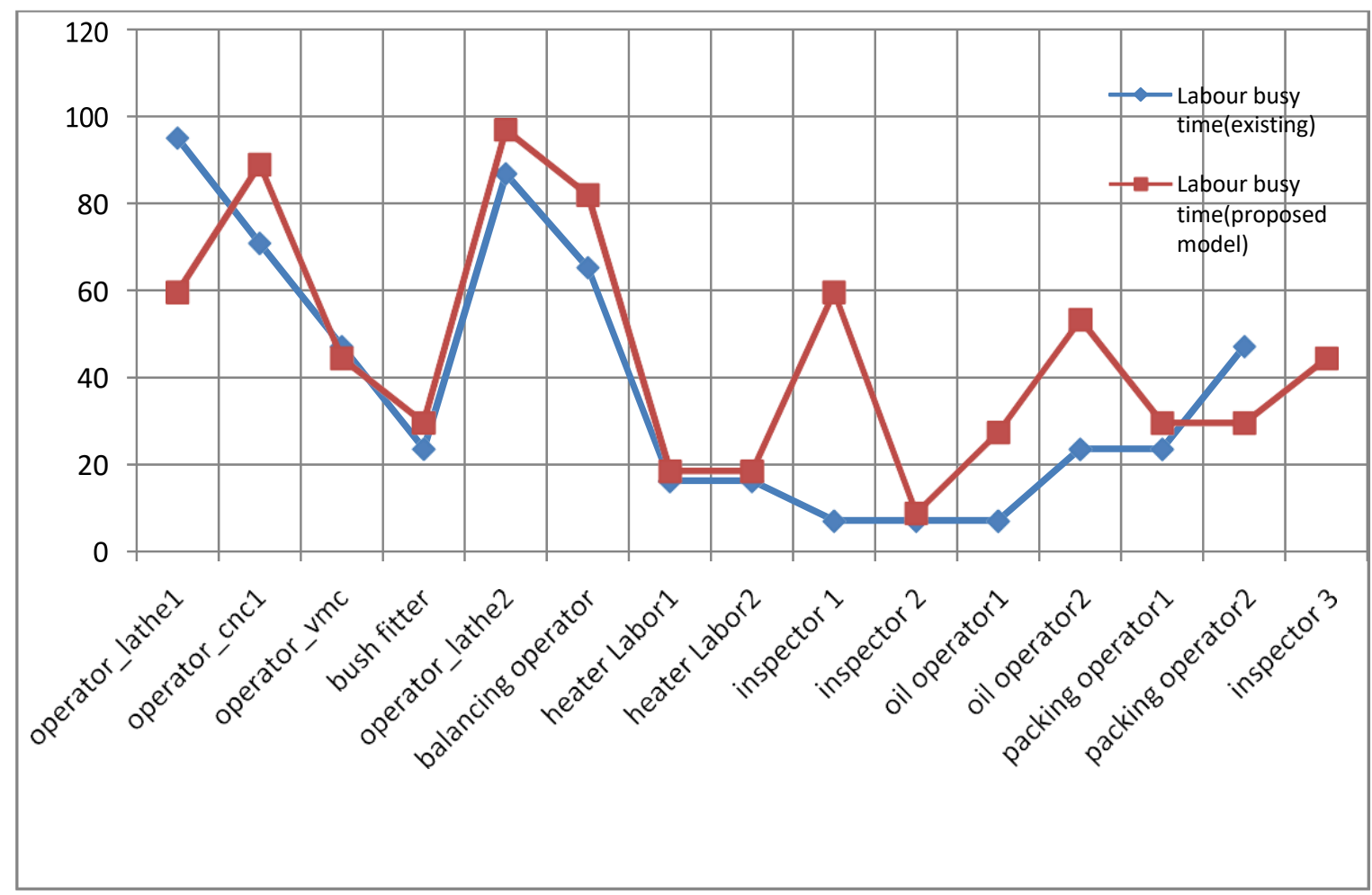

Figure 9 Comparison by labor busy time

The table below also shows the statistics of how the significant amount of improvement has been done with optimization of various parameters.

\begin{tabular}{|c|c|c|c|}
\hline No. & Model & $\begin{array}{l}\text { Throughput per } \\
\text { shift }\end{array}$ & Throughput per day \\
\hline 1. & Existing system & 112 & 336 \\
\hline 2. & $\begin{array}{l}\text { Model with additional lathe and } \\
\text { labour }\end{array}$ & 130 & 390 \\
\hline 3. & $\begin{array}{l}\text { Labour Optimization (Inspection to } \\
\text { Packing) }\end{array}$ & 115 & 345 \\
\hline 4. & $\begin{array}{l}\text { Labour Optimization(Inspection to } \\
\text { Ring Fitting) }\end{array}$ & 114 & 342 \\
\hline 5. & $\begin{array}{l}\text { Combined Labour optimization } \\
\text { (Inspection to Packing and Inspection } \\
\text { to Ring Fitting) }\end{array}$ & 116 & 348 \\
\hline 6. & Proposed model & 134 & 402 \\
\hline
\end{tabular}


International Journal of Design and Manufacturing Technology (IJDMT), ISSN 0976 - 6995(Print), ISSN

0976 - 7002(Online) Volume 2, Issue 1, January-December (2011), ( ) IAEME

Technical and economical properties of conceptual system can be analyzed by means of simulation model. Here we had justified the use of simulation techniques in the manufacturing system, result shows increase in throughput and work in progress of system by reducing bottlenecks at different workstation. Hence simulation is proved to be very much useful tool for optimizing the manufacturing system.

It would rather be better to make use of such simulation studies for optimizing the parameters and obtain better shop floor designs while establishing new manufacturing system.

\section{REFERENCES}

[1] Averill M. Law , Micheal G.McComas 'Simulation of Manufacturing Systems' proceeding Winter Simulation conference 1997,USA.

[2]Anu Maria 'Introduction to modeling \& simulation' proceeding Winter Simulation conference ,1997,USA.

[3]Scott Miller, Dennis Pegden,' Introduction To Manufacturing Simulation' Proceedings of the 2000 Winter Simulation Conference, USA.

[4]Law, A.M. and D.W. Kelton. 'Simulation Modeling and Analysis ( $3^{\text {rd }}$ Ed.)', McGrawHill, New York, 2000.

[5] Jackson, M., and Johansson, C. (1997) 'Real Time Discrete Event Simulation of a PCB Production System for Operational Support'. Proceedings of the 1997 Winter Simulation Conference, pp. 832-837.

[6] M A Palsodkar, V B Suryawanshi, M S Kirkire, "Manufacturing System Simulation \& Reengineering for Improved Throughput", proceedings of International conference on Latest trends in Simulation modeling \& analysis (COSMA 2009), National Institute of Technology Calicut, India.

[7] M A Palsodkar, V B Suryawanshi, M S Kirkire, "Evaluation of manufacturing System by discrete event simulation", proceedings of International conference (APORS 2009) organized by Association of Asia Pacific operational research society , Jaipur, India.

[8] M A Palsodkar, V B Suryawanshi, M S Kirkire, "Discrete event simulation and reengineering to improve performance of manufacturing system", proceedings of $9^{\text {th }}$ global conference on flexible systems management, (GLOGIFT 2009) at National Institute of Industrial Engineering (NITIE), Powai, Mumbai. 